\title{
PENGEMBANGAN ALAT DESINFEKSI AIR MINUM DENGAN UVGI (ULTRAVIOLET GERMECIDAL IRRADIATION) BERBASIS ARDUINO
}

Harmawan Febrianto, ${ }^{2}$ Massus Subekti, ${ }^{3}$ Nur Hanifah Yuninda

${ }^{1,2,3}$ Pendidikan Teknik ElektroTeknik Elektro, Universitas Negeri Jakarta

${ }^{1}$ E-mail: harmawantecno@gmail.com

\begin{abstract}
The purpose of this study is to make a drinking water desinfector device by irradiating ultraviolet light (UV) based on Arduino. The device can provide information specific to large-intensity UV lamps in optimal perfomance to desinfection drinking water, as well as a signal to the operator if, the intensity of the UV lamps has decreased resulting in water flow will be closed automatically controlled by on Arduino. This study uses a method of Research and Development (Research and Development), which includes planning, requirements analysis, design, and implementation of the system. System requirements necessary in this study are ultraviolet sensor that can measure the magnitude and intensity of ultraviolet rays water rate sensor to measure the flow rate of water entering on this instrument. In this case serves to monitor the UV lamp specifically keoptimalan and Arduino will process the input results for the solenoid valve opens automatically and gives an alarm signal to the operator.

These results indicate that the instrument disinfection of drinking water with UVGI-based Arduino has managed to work out where these tools can provide large information intensity of UV rays as well, can give an alarm signal to the operator and the control solenoid valve in order to shut off the flow of water automatically as a follow security if not in accordance with a predetermined set point, namely at the point of maximum 978 lux with a water flow rate $3 \mathrm{~L} / \mathrm{min}$ based microbial testing in the laboratory. At this point is the most optimal point in reducing bacteria which amounted to $94.57 \%$ or the remaining 25 colonies / $\mathrm{ml}$ of the total number of bacteria before exposed to UV light that is 460 colonies / $\mathrm{ml}$. It is adjusted by the standard (SNI 7388: 2009-14.1.1.2) with a maximum limit of microbial contamination in drinking water is 100 colonies $/ \mathrm{ml}$.
\end{abstract}

Keywords : Disinfection, Ultraviolet Light, Optimal, Microbe.

\begin{abstract}
Abstrak
Tujuan penelitian ini adalah membuat suatu alat desinfeksi air minum dengan penyinaran lampu ultraviolet (UV) berbasis Arduino. Alat ini dapat memberikan informasi secara spesifik terhadap besar intesitas lampu UV dalam keoptimalannya untuk medesinfeksikan air minum, serta memberikan sinyal kepada operator apabila, intesitas lampu UV telah menurun dan akan mengakibatkan aliran air akan tertutup secara otomatis yang dikendalikan dengan Arduino. Penelitian ini menggunakan Metode Penelitian dan Pengembangan (Research and Development) yang meliputi perencanaan, analisis kebutuhan, perancangan, dan implementasi sistem. Kebutuhan sistem yang diperlukan pada penelitian ini adalah : sensor ultraviolet yang dapat mengukur besar intesitas sinar ultraviolet dan sensor laju air untuk mengukur kecepatan aliran air yang masuk pada alat ini. Dalam hal ini berfungsi memantau keoptimalan lampu UV secara spesifik serta Arduino akan memproses hasil input tersebut untuk membuka solenoid valve secara otomatis dan memberikan sinyal alarm kepada operator.

Hasil penelitian ini menunjukan bahwa alat desinfeksi air minum dengan UVGI berbasis Arduino telah berhasil bekerja dimana alat ini dapat memberikan informasi besar intesitas sinar UV serta, dapat memberikan sinyal alarm kepada operator dan mengendalikan solenoid valve agar bisa menutup aliran air secara otomatis sebagai tindak keamanan jika tidak sesuai dengan set point yang telah ditentukan, yakni pada titik maksimal 978 lux dengan kecepatan aliran air 3 L/min berdasarkan pengujian mikroba di laboratorium. Pada titik ini adalah titik yang paling optimal dalam mereduksi bakteri yakni sebesar $94,57 \%$ atau tersisa $25 \mathrm{Koloni} / \mathrm{ml}$ dari angka total bakteri sebelum disinari sinar UV yakni $460 \mathrm{koloni} / \mathrm{ml}$. Hal ini disesuaikan oleh standar (SNI 7388:2009-14.1.1.2) dengan batas maksimum cemaran mikroba pada air minum sebesar $100 \mathrm{koloni} / \mathrm{ml}$.
\end{abstract}

Kata Kunci : Desinfeksi, Sinar Ultraviolet, Optimal, Mikroba

\section{PENDAHULUAN}

Hingga saat ini, akses masyarakat terhadap air minum secara nasional baru mencapai $47,71 \%$ atau jauh dari target MDGs pada tahun 2015 yaitu sebesar 68,87\% (Pokja AMPL, 2012). Masalah tersebut Salah satu faktor penyebab adalah terkontaminasinya air dalam proses pengaliran karena jaringan distribusi yang kurang layak dan kondisi perpipaan yang buruk sehingga menyebabkan tingginya angka kebocoran air sehinggat terjadinya kontaminansi salahsatunya terhadap bakteri. Dalam meminimalisir kontaminasi bakteri terhadap air minum yang akan dikosumsi oleh masyarakat, salah satunya 
dengan Metode desinfeksi menggunakan metode penyinaran lampu ultraviolet ( 200-260 nm) atau UVGI (Ultraviolet Germicidal Irradiation ) merupakan cara sederhana untuk membunuh bakteri secara cepat, efektif dan tidak membutuhkan energi yang besar. Namun penyinaran lampu ultraviolet memiliki kelemahan dalam intensitas radiasi diakarenakan seiring lamanya penggunaan serta ketidakstabilan laju air yang berakibat menurunnya kualitas air dari standar yang telah ditetapkan. Hingga saat ini dalam proses desinfeksi air minum dengan lampu ultraviolet masih menggunakan alat hour meter, dimana hanya bekerja dengan ultraviolet dan memberikan sinyal kepada operator jika terjadi kerusakan terhadap lampu memantau lama waktu pemakaian lampu atau ketidak optimalan lampu UV dalam mendesinfeksikan air dengan berparameter usia lampu atau lama pemakaian. Sehingga hour meter belum memberikan parameter yang spesifik dalam menentukan kinerja lampu ultraviolet dalam mendesinfeksikan bakteri pada air minum. Dengan masalah tersebut maka melatar belakangi penelitian untuk membuat suatu alat yang dapat memberikan informasi besarnya intesitas sinar ultraviolet setelah sekian lama digunakan. Parameter tersebut diambil dikarenakan, bahwa kefektifan lampu UV dipengaruhi dalam berbagai faktor salahsatunya selain lama pemakaian yakni besar intesitas sinar UV dan lama waktu pemaparan, Lekang.(2013:122)

\section{METODE}

\section{Waktu dan Tempat Penelitian}

Tempat pembuatan dan pengujian prototipe UV-TRON (Ultraviolet Smart Protection Control) dilaksanakan di Laboratorium PT.Monysaga Prima Bekasi dan Laboratorium Mikrobiologi FMIPA Universitas Negeri Jakarta. Dalam rentang waktu bulan Februari - November 2016.

\section{Alat dan Bahan}

Alat: Gergaji, Multimeter Analog, Multimeter Digital, Kabel Jumper, Gerinda, Las Elektroda, Kunci Ukuran 10, Kunci Ukuran 11, Tang Potong, Tang Jepit, Obeng Kembang, Obeng Minus, Lux Meter PMA2200.

Bahan : Lampu Sankyo Denki Ultraviolet 20 Watt 5 GPM, Water Flow Sensor SEN-HZ21WA dengan kapasitas maksimum 60L/min, UVM30A (sensor), Relay 6 VDC, Arduino Uno R3, Saklar Push Button, Saklar SPDT, LCD (Liquid Crystal Display) Ukuran 16×2, PCB (Printed Circuit Board), Panel Box, Buzzer, Pompa Air Kapasitas $3000 \mathrm{~L} / \mathrm{H}$

\section{Prosedur Penelitian}

Tahapan yang dilakukan dalam proses pengerjaan penelitian ini ditunjukkan pada bagan alir sebagai berikut:

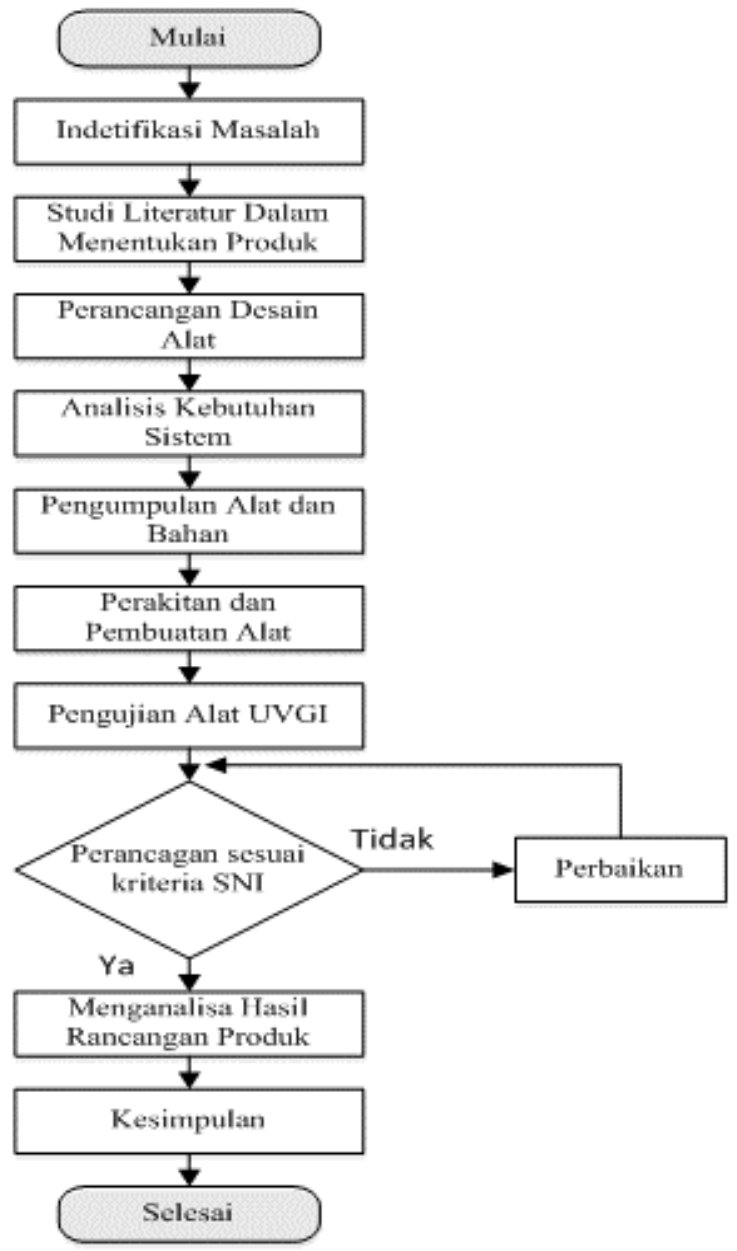

Gambar 1. Diagram Alir Tahapan Penelitian

\section{Tahap Perencanaan dan Perancangan Prototipe}

Sebelum melakukan pengujian alat, peneliti melakukan berbagai perancangan dalam pembuatan prototipe ini karena dalam hal ini yang menjadi pertimbangan dalam melakukan suatu pengujian prototipe.

\section{Spesifikasi:}

Daya Lampu UV :20 Watt

Merek Lampu UV :Sankyo Denki G20T10

Panjang Tabung UV :54 cm

Jenis Pipa :PPR (Polypropylane Random)

Diameter Lampu UV: 1.25 inch $=3.2 \mathrm{~cm}$

Diameter Tabung Reaktor UV: 2 inch $=5.08 \mathrm{~cm}$ 


\section{Perencanaan Input Dan Output}

Dalam melakukakan suatu perancangan sistem dilakukanya perencanaan I/O pada sistem dalam prototipe ini.

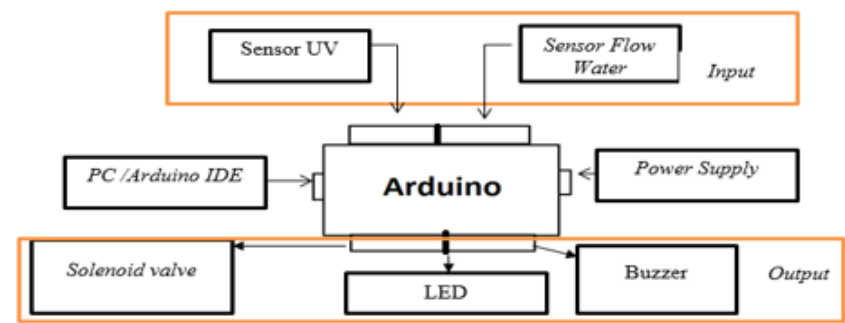

Gambar 2. Perencanaan I/O

Wiring Diagram Prototipe Alat Kontrol UVGI

Dalam pembuatan prototipe ini dibangun perancangan skema wearing diagram pada panel kontrol dimana pada wearing ini diperlihatkan secara detil susunan rangkaian listrik dan komponen-komponen yang berada pada panel kontrol.

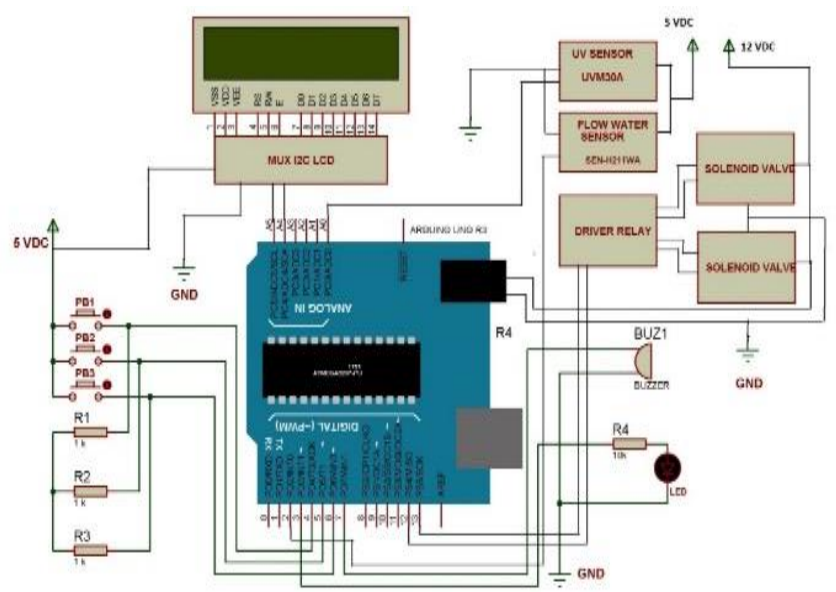

Gambar 3. Wiring Diagram Panel Kontrol UVGI Berbasis Arduino

\section{Teknik Pengumpulan Data}

Dimana pun dalam pengujian alat ini $h$ disesuaikan dengan tingkat kepresisian alat ukur dan sensor maka diperlukan pengujian sensor

\section{HASIL DAN PEMBAHASAN}

\section{Konsep dan Desain Rancangan Alat}

Dalam pembuatan perancangan desain prototipe ini meliputi bagian desain alat kontrol dan desain tabung reaktor lampu ultraviolet.

\section{1) Realisasi Alat Desinfeksi UVGI Berbasis}

\section{Arduino}

Prototipe kontrol dipasang untuk memonitoring dan mengendalikan solenoid valve dan buzzer disaat sensor UV dan sensor water flow membaca suatu nilai dibawah kriteria optimal kerja dari lampu UV. Hal ini mengakibatkan solenoid valve tertutup secara otomatis agar aliran air tidak dapat memasuki tabung reaktor UV dan air tidak dapat didistribusikan
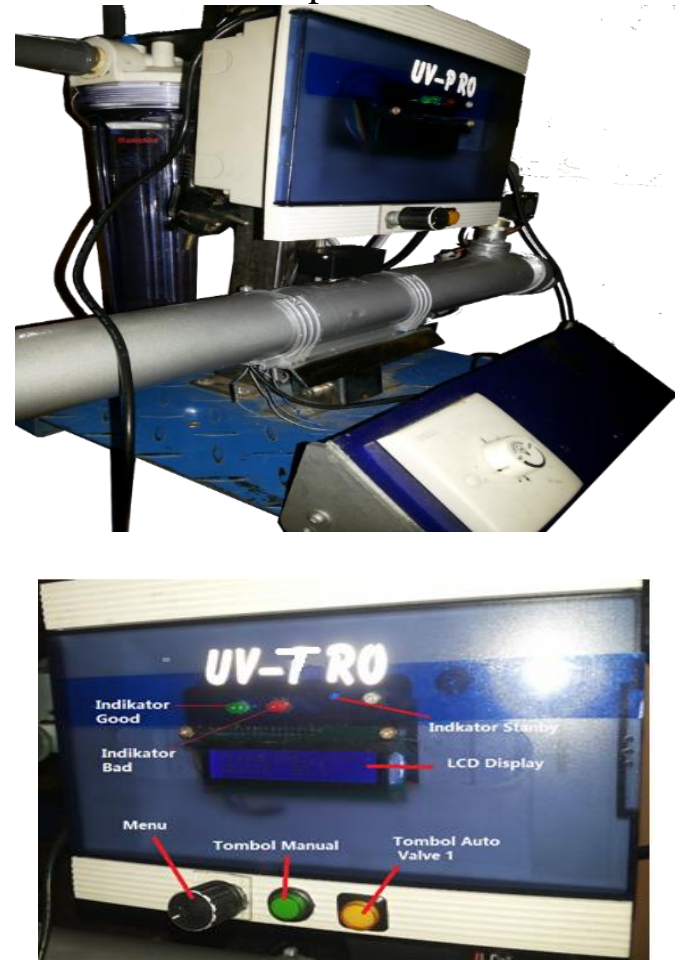

Gambar 4. Realisasi Alat Desinfeksi Air Minum Dengan UVGI Berbasis Arduino

\section{Pengujian Hardware}

1) Pengujian Kalibrasi Sensor Ultraviolet

Dalam pengujian ini digunakannya kalibrasi sensor agar sesuai dengan nilai sensor saat sebelum diberi tabung dan sesudah diberi tabung yang telah terisi oleh air bersih.

Tabel 1. Pengujian Kalibrasi Sensor Ultraviolet

\begin{tabular}{ccccc}
\hline No. & $\begin{array}{c}\text { Tingkat Besar } \\
\text { Intesitas } \\
\text { (Intesity Rate) }\end{array}$ & $\begin{array}{c}\text { ADC } \\
\text { sensor }\end{array}$ & $\begin{array}{c}\text { Tegangan } \\
\text { Sensor (mili- } \\
\text { Volt DC) }\end{array}$ & $\begin{array}{c}\text { Intesitas } \\
\text { (LUX) }\end{array}$ \\
\hline 1 & $100 \%$ & 7 & 97.656 & 1015 \\
2 & $75 \%$ & 5 & 78.125 & 978 \\
3 & $50 \%$ & 2 & 58.594 & 762 \\
\hline
\end{tabular}

2) Pengujian Sensor Flow Water Sensor

Pengujian Sensor Flow water untuk mengukur kecepatan debit air dimana agar dapat mengendalikan laju air yang melewati tabung reaktor lampu Ultraviolet, agar sesuai dengan kapasitas waktu pemaparan lampu Ultraviolet untuk membunuh mikroba dalam air. Pengujian sensor ini dengan pengamatan sensor menggunakan software IDE Arduino dengan perbandingan menggunakan gelas Ukur dan stopwatch dengan perulangan tiga kali dalam pengambilan data. 
Tabel 2. Pengujian Hasil Kalibrasi Sensor Water Flow

\begin{tabular}{|c|c|c|c|c|c|}
\hline \multirow[t]{2}{*}{ No } & \multicolumn{3}{|c|}{$\begin{array}{l}\text { Pembacaan Sensor } \\
\text { Water Flow }(\mathrm{L} / \mathrm{min})\end{array}$} & \multirow{2}{*}{$\begin{array}{c}\text { Alat Ukur } \\
\text { Debit } \\
(\mathrm{L} / \mathrm{min})\end{array}$} & \multirow[t]{2}{*}{ Deviasi } \\
\hline & Min & Max & Rata-rata & & \\
\hline 1 & 6.56 & 6.67 & 6.615 & 6.67 & 0.055 \\
\hline 2 & 5.55 & 5.61 & 5.58 & 5.45 & 0.130 \\
\hline 3 & 3.89 & 3.78 & 3.835 & 3.75 & 0.085 \\
\hline 4 & 2 & 2.11 & 2.055 & 1.9 & 0.155 \\
\hline 5 & 1 & 1.11 & 1.055 & 0.9 & 0.155 \\
\hline
\end{tabular}

\section{Pengujian Laboratorium Kinerja Alat}

1) Tahap Pengujian Sampel Air Terhadap Intesitas Sinar UV

Dalam tahap ini dimana dilakukan pengujian sampel air yang akan mengalir ke tabung reaktor lampu ultraviolet dengan merubah besar intesitas lampu UV, hal ini dilakukan dengan cara mengurangi tegangan, hal ini dilakukan dimana melihat apakah kuman atau mikroba dapat terbunuh saat intesitas lampu ultraviolet berubah. Dimana dalam intesitas yang digunakan yakni 1015 Lux, 978 Lux dan 763 Lux. Hasil pada pengujian ini menunjukkan besarnya intensitas UV berpengaruh terhadap jumlah mikroba (Gambar. 5). Intensitas UV yang terbaik dalam menurunkan jumlah mikroba yaitu pada titik intensitas 978 lux dengan jumlah mikroba 10 $\mathrm{cfu} / \mathrm{ml}$. Titik intensitas sinar tersebut mampu menurunkan jumlah bakteri hingga $97.83 \%$ dari jumlah bakteri kontrol (sebelum di UV). Jumlah bakteri meningkat pada intensitas 762 lux sebesar 65.5 koloni $/ \mathrm{ml}$.

Pada pengujian sampel diambil pada kecepatan flowrate kurang lebih sebesar 3 $\mathrm{L} / \mathrm{min}$ diambil dari titik tengah pada flowrate maksimal yang dilalui oleh prototipe ini sebesar $6 \mathrm{~L} / \mathrm{min}$.

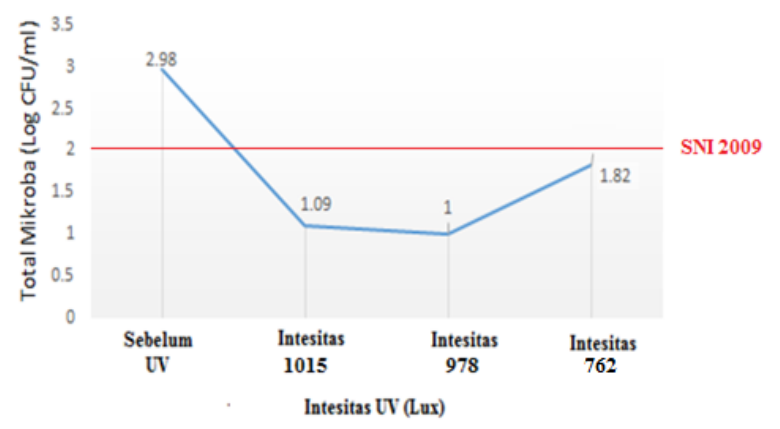

Gambar 5. Pengujian Pengaruh Besar Intesitas Terhadap Jumlah Bakteri
2) Tahap Pengujian Sampel Air Terhadap kecepatan aliran air

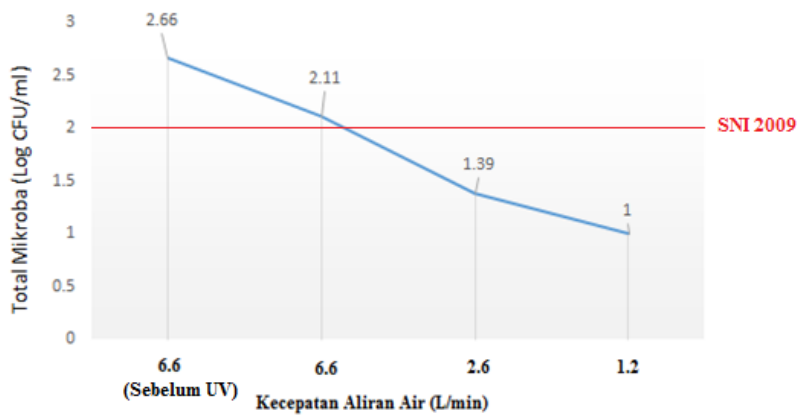

Gambar 6. Pengujian Pengaruh Intesitas Sinar UV

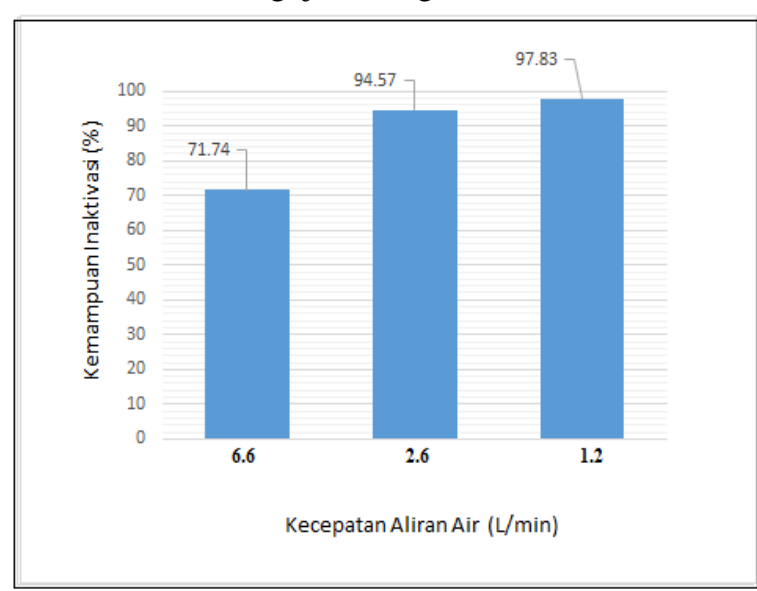

Gambar 7. Grafik Kemampuan Inaktivasi Mikroba Dengan Pengaruh Kecepatan Aliran Air

Hasil pengujian pengaruh perubahan kecepatan air menunjukkan bahwa terjadi penurunan jumlah mikroba hingga 10 koloni/ml atau kemampuan inaktivasi mikroba dengan menggunakan desain prototipe ini sebesar $97.83 \%$ dalam kecepatan aliran air 1.2 $\mathrm{L} /$ min (Gambar 4.9). Kemampuan inaktivasi ini menurun pada titik kecepatan aliran air 6.6 $\mathrm{L} / \mathrm{min}$ yaitu sebesar $71.74 \%$. Hal ini dikarenakan pada kondisi tersebut menggunakan desain prototipe yang hanya mampu bekerja pada kecepatan aliran air maksimum $3.3 \mathrm{~L} / \mathrm{min}$. Pengaruh kecepatan aliran air berpengaruh pada besarnya kekuatan lampu UV yang akan digunakan, dimana semakin cepat kecepatan aliran air maka waktu yang dipaparkan sinar UV terhadap air akan semakin cepat begitu pun sebaliknnya (International Guard,2010).

\section{Pengujian Sisitem Perangkat Lunak}

Pengujian perangkat lunak meliputi pengujian perangkat sensor input dan perangkat output dengan pengujian bahasa pemrograman menggunakan software IDE Arduino. 
Tabel 4. Keterangan Perubahan Intesitas Sinar UV

\begin{tabular}{ccc}
\hline Besar Intesitas & ADC Sensor & Keterangan \\
UV (Lux) & UV & \\
\hline $1015-811$ & $7-4$ & Good \\
780 & 3 & Medium \\
$<780$ & $<3$ & Bad \\
\hline
\end{tabular}

Tabel 5. Keterangan Perubahan Kecepatan Aliran Air

\begin{tabular}{cc} 
Besar Kecepatan & Keterangan \\
Aliran Air (L/min) & \\
\hline $1-3$ & Diperbolehkan \\
$>3$ & Tidak Diperbolehkan \\
\hline
\end{tabular}

Tabel 6. Hasil pengujian sistem alat kontrol UV

\begin{tabular}{ccccccc}
\hline & \multicolumn{3}{c}{ INPUT } & \multicolumn{5}{c}{ OUTPUT } \\
\cline { 2 - 7 } No. & $\begin{array}{c}\text { Sensor } \\
\text { Water } \\
\text { UV }\end{array}$ & $\begin{array}{c}\text { Llow } \\
\text { (L/min) }\end{array}$ & Hijau & $\begin{array}{c}\text { LED } \\
\text { Merah }\end{array}$ & Buzzer & SV1 \\
\hline 1 & 6 & 3 & HIGH & LOW & LOW & LOW \\
2 & 5 & 5 & LOW & HIGH & HIGH & HIGH \\
3 & 5 & 4 & LOW & HIGH & HIGH & HIGH \\
4 & 5 & 1 & HIGH & LOW & LOW & LOW \\
5 & 4 & 3 & HIGH & LOW & LOW & LOW \\
6 & 4 & 2 & HIGH & LOW & LOW & LOW \\
7 & 3 & 5 & LOW & HIGH & HIGH & LOW \\
8 & 2 & 2 & LOW & HIGH & HIGH & HIGH \\
9 & 1 & 4 & LOW & HIGH & HIGH & HIGH \\
10 & 0 & 6 & LOW & HIGH & HIGH & HIGH \\
\hline
\end{tabular}

\section{KESIMPULAN DAN SARAN}

\section{Kesimpulan}

Setelah alat ini dibuat dan diuji coba maka dapat disimpulkan bahwa alat desinfeksi air minum dengan UVGI berbasis Arduino telah berhasil bekerja dimana alat ini dapat memberikan informasi besar intesitas sinar UV serta, dapat memberikan sinyal alarm kepada operator dan mengendalikan solenoid valve agar bisa menutup aliran air secara otomatis sebagai tindak keamanan jika tidak sesuai dengan set point yang telah ditentukan, yakni pada titik maksimal dibawah 978 lux dengan kecepatan aliran air 3 L/min berdasarkan pengujian mikroba di laboratorium. Pada titik ini adalah titik yang paling optimal dalam mereduksi bakteri yakni sebesar $94,57 \%$ atau tersisa $25 \mathrm{Koloni} / \mathrm{ml}$ dari angka total bakteri sebelum disinari sinar UV yakni $460 \mathrm{koloni} / \mathrm{ml}$. Hal ini disesuaikan oleh standar (SNI 7388:2009-14.1.1.2) dengan batas maksimum cemaran mikroba pada air minum sebesar 100 koloni/ml.

\section{Saran}

Penulis memiliki saran untuk para pembaca guna menerangkan dan melengkapi kelemahan dalam pengujian prototipe ini yaitu sebagai berikut:
1. Dalam membuat alat ini, diperlukan pengujian lanjutan terhadap pengujian karakteristik terhadap jenis mikroba yang dapat di desinfeksikan oleh alat ini.

2. Dimana dalam penggujian pada penelitian berikutnya dibuat sistem kontrol yang lebih sederhana yang mampu operator dapat mengoperasikannya dengan baik.

3. Dalam penelitian berikutnya, lebih merangkap dan pengujian terhadap efektifitas sistem pembacaan sensor UV secara mendalam agar dapat mendeteksi secara tepat mengetahui penurunan intesitas sinar UV.

4. Dibutuhkan uji mendalam terhadap karakteristik lampu UV kategori $\mathrm{C}$ atau germicidal lamp berdasarkan besar penurunan intesitas sinar UV.

\section{DAFTAR PUSTAKA}

Anang Lastriyanto,dkk. (2011). Desain dan Uji Prototipe Alat Pasteurisasi Susu Berbasis Teknologi Irradiasi Ultraviolet Vol.2. Universitas Brawijaya.

Bolton,W. (2006). Sistem Instrumentasi dan Sistem Kontrol.Erlangga. Jakarta.

Badan Standardisasi Indonesia, 2006. Standar Nasional Indonesia 04-6629: 2006, Jakarta: BSN.

Bakhsi, U.A. (2009). Feedback Control System. Pune: Technical Publication Pune.

Kadir, Abdul. (2014). Buku Pintar Pemrograman Arduino. Yogyakarta: MediaKom.

Lekang,Odd- Ivar. 2007. Aqualculture Engineering. Blackwell Publishing. Singapore.

Nana S.S \& Sugeng. R. 2008.Ultraviolet Sebagai Salah Satu Alat Desinfektan Penting Di Pembenihan: Rekayasa dan Desain . Takalar: BBAP Takalar

Udi Putra N. S. S, M. Syaichuddin, S. Faridah. Tamrin. (2007). Efektifitas Ultraviolet Sederhana dalama mereduksi bakteri pathogen didalam media air budidaya. Prosiding Indonesia Aqualculture 2007. Direktorat Jendral Perikanan Budidaya.

USEPA. 2003. Ultraviolet Desinfection Guidance Manual. Draft. Wahsington DC, Office of Ground Water and Dringking Water, United States Enviromental Protection Age. 